\title{
SIGNIFICANT PERSONALITY IN THE SHADE OF LECTORATE IN MUSEUM STUDIES? A CONTRIBUTION TO THE 135TH BIRTH ANNIVERSARY OF JAROSLAV HELFERT

\section{OTAKAR KIRSCH}

In the rich and in many regards complicated development of Czech (Czechoslovak) museology we can notice significant personalities, who either remained unknown to the foreign academic community, or are known to them through a specific activity which has been interpreted as an important milestone in the history of the discipline. This also is the case with Jaroslav Helfert (1883-1972), who has been mentioned in the above circles almost exclusively as the implementer of one of the oldest institutional forms of museum studies in universities. This legacy was also directly followed by later External Chair of Museology in Brno, as it was expressed by Zbyněk Zbyslav Stránský. Lesser-known are Helfert's original opinions which surpassed the contemporaneous professional approaches to the given problem and tended to a general museological way of thinking, determined by foreign influences and by the democratic milieu of the so-called First (19181938) and Third Czechoslovak Republic (1945-1948). The presented personal profile on the occasion of the 135th birth anniversary is thus intended to introduce in a more complex manner the ideas of this Czech museum scientist and the related activities in the field of museums.

The formation of Helfert's opinions was fundamentally influenced

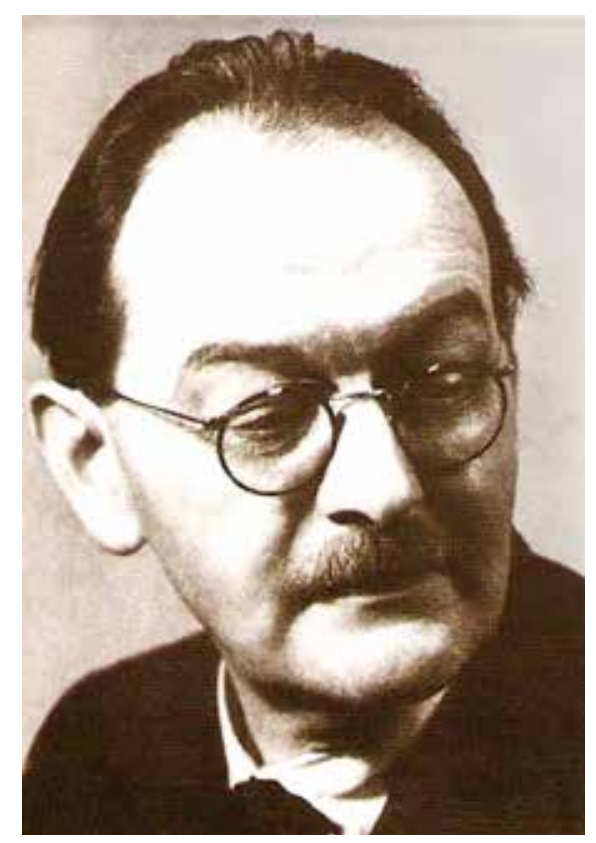

Fig. 1: Jaroslav Helfert (source: Internetová encyklopedie dějin Brna [online]. [accessed 2018-10-21]. Available from www: < https://encyklopedie.brna.cz/ home-mmb/?acc $=$ profil_osobnosti\&load $=2371>$.)

by his family background.

Among his ancestors we can find individualities, who significantly determined the cultural history of Austro-Hungarian Monarchy, particularly the sphere of preservation of historical monuments (Josef Helfert, Josef Alexander Helfert). Further professional specialisation of the emergent prominent personality in Czechoslovak museum science was boosted by his studies in the fields of art history and history at the universities of Prague and Vienna. At the latter university he became student of leading figures in the so- called Vienna School of Art History, Max Dvořák and Alois Riegl. This was one of the reasons why Helfert was later defined by his colleagues as a "suitable synthesis of a monument conservationist and a museum worker". His museum career, however, was already since 1909 inseparably connected with the most significant Moravian (historical territory of present-day Czech Republic) institution - the Moravian Museum (hereinafter MZM). In 1923 he was appointed director in this institution, after a somewhat controversial removal of the German part of management, which was until then composed of both Czech and German members. Helfert then held the office, except the period of Nazi occupation, until the communist coup in 1948. After being retired he did not give up his active professional life - until his death in 1972 he was engaged in regional and cultural studies.

Helfert's museological engagement was primarily based on his activities in the MZM, where he, first as a curator, significantly contributed to completion and quality improvement of art collections. Later, as the director, he attempted to carry out a general transformation of the institution by applying a scientific and museological approach to individual museum activities. This process, among other things, comprised a general restructuring of museum collections (including 
the exchange of collection sets with other institutions in Brno) and their unified presentation according to individual periods or styles. But he also focused his efforts on the build-up of Moravian regional museums "managed by professionals instead of amateurs". In Helfert's vision, MZM was intended to become the only scientific institution which would have its branches in predetermined locations and through these branches it would influence the activities of all components of the local museum network. In his imagination, the focal point of museum activities was purposefully and sensibly spread over all Moravian regions (inclusive of the specialisation of individual institutions in significant local topics) with a single methodical centre. As a representative of a traditional institution, which also was quite progressive at that time, he soon found his way to governing bodies of Czechoslovak museum sphere. He became member of the advisory board of the Ministry of Schools and National Education (he was also responsible for museums) and was intensively engaged in the professional organisation of Czechoslovak museum workers titled Union of Czechoslovak Museums, first as a member of the executive and later as the Chairman. In this post he endeavoured to raise the overall level of museums, particularly the smaller ones, and to manage their activities not by a priori formulations but on the basis of a thorough study of their local background.

These efforts made Helfert contemplate more generally on the museum phenomenon, specifically on the issue of general purpose and function of museums. The Brno museologist regards these amenities as a new type of cultural institutions which had a lot to offer to society of that time. According to him, the public is more and more interested in their activities and an active participation in them, as a result of the development of European democracy. In the so-called direct public service he included the providing of professional impulses and materials for scientific purposes, illustrative supplements to school teaching, and an extended and deepened education for general public. By these three tasks (scientific, pedagogical, educational) the museum integrates into the structure of scientific and cultural activities in the state and nation. Helfert saw the main attributes of the then museums in "public presentation" and "professionalization" of museum work. Within this scope he then pursued 4 basic principles 1) continuously get to know the monuments in one's own district, 2) collect for one's own museum in accordance with its programme, and acquire objects of different character for another museums, 3) safeguard the acquired objects (inventory, cataloguing, conservation, restoration), 4) present the objects to be used (installation, publication). In his work he also tried to analyse the principles of individual museum activities, above all acquisition. According to him, museums should not turn into “...storehouses for discarded props, splendid rarities and curiosities serving as decorations", but into institutions with own research programme focused on objects of all kinds, whose material or representative value does not play the fundamental role. He considers the collection-building activity per se not the research purpose, but the research result. Helfert paid a great deal of attention to professional processing of collection objects; he called for the build-up of a database of objects which do not belong to museum property, because "Museum is not only what it has but also what it knows of". In connection with presentation activity he pointed to the fact that museum is a scientific institution, which, however, does not serve purely scientific purposes. With regard to installation, which is primarily targeted at nonprofessional audience (professionals can primarily use depositories for research purposes), he recommends to exhibit the collections of museum objects in the form of recurrent temporary exhibitions. This approach prevents from frequent damages of material and increases the interest in the museum itself. In the case of an insufficient amount of suitable originals, the original objects can be replaced by substitutes (photographs, graphs, etc.), which, however, should not represent the fundamentals of museum presentation activities.

The increasing responsibility of museums in the field of public relations and curation of collections brought in Helfert's conception increased demands laid on museum staff. Museum workers, apart from their inner discipline (e. g. to not violate the collection-building museum strategy) and suppression of the feeling of own infallibility (e. g. the capability of consulting the problem with appropriate authority), also need an in-depth museological training. Helfert succeeded in realising this platform by establishing the Lectorate in Museum Studies in 1921 when he was appointed lecturer in museum studies at the Faculty of Arts of the Masaryk University in Brno. Even though museum circles of that time did not fully accept the Lectorate for many reasons, the leading personality in this institution was able to defend and shield its activity in practical and professional matters. Although the lectures and seminars taught in 1922-1951 
(with more than six-year-long break caused by war events) rather accentuated the problem of museum practice (for example the collection-building activity of museums, recording, conservation or exhibition making), they also tended to solve some theoretical and theoretic-organisational questions closely related to the overall situation in Czechoslovak museums. Even though the sphere of its activity was rather limited to the territory of Moravia, the
Lectorate educated many workers who later significantly participated in the development of museum institutions throughout the then Czechoslovakia.

\section{OTAKAR KIRSCH}

Department of Archaeology and Museology, Faculty of Arts, Masaryk University, Brno, Czech Republic 